\title{
A rare case of spontaneous posterior wall rupture in an unscarred uterus during labour
}

\author{
Kirty Nanda*, Shakun Singh, Vandana Dhama, Rachna Choudhary, Renu Azad
}

Department of Obstetrics and Gynecology, LLRM Medical College, Meerut, Uttar Pradesh, India

Received: 19 June 2017

Accepted: 19 July 2017

\section{*Correspondence:}

Dr. Kirty Nanda,

E-mail: drkirtynanda20@gmail.com

Copyright: (C) the author(s), publisher and licensee Medip Academy. This is an open-access article distributed under the terms of the Creative Commons Attribution Non-Commercial License, which permits unrestricted non-commercial use, distribution, and reproduction in any medium, provided the original work is properly cited.

\begin{abstract}
Uterine rupture is a dreaded catastroph in obstetrics with a high incidence of maternal and fetal morbidity. In developing Country, the overall prevalence widely varies from 1 in 2,000 to 1 in 200 deliveries. Uterine rupture in an unscarred uterus is a rare event and only a finger countable cased have been reported on posterior rupture of uterus in unscarred uterus. We here presenting a case of spontaneous posterior rupture of an unscarred uterus. Our patient was 38 years old grand multipara, a 6th gravida female with 4 parity, 1 abortion last year and 3 live issues. She was 9 months of gestation with previous all normal vaginal deliveries. This time she had a uterine rupture in the lower segment of posterior wall of uterus during labour. The rupture was unrepeatable, so we have to do hysterectomy. This case points out to keep this catastroph in mind in multiparas with unscarred uterus and to be prepared for the same while assisting a normal vaginal delivery.
\end{abstract}

Keywords: Posterior wall uterine rupture, Uterine rupture, Unscarred uterus

\section{INTRODUCTION}

Uterine rupture may be primary, defined as occurring in a previously intact or unscarred uterus, or may be secondary which is associated with a preexisting myometrial incision, injury, or anomaly. Some of the causes of primary rupture are history of previous abortion followed by curretage, sharp or blunt trauma to uterus like assault, vehicular accidents, bullets, knives or history of silent rupture in previous pregnancies.

Persistent, intense, spontaneous contractions, labor stimulation by oxytocin or prostaglandins, intra amniotic instillation by saline or prostaglandins, perforation by internal uterine pressure catheter, external trauma either by sharp or blunt, external version or uterine over distention due to macrosomic fetus, hydramnios, multifetal pregnancy are some of the causes that results in rupture in the present pregnancy. ${ }^{1}$ Rupture of the unscarred pregnant uterus is a rare event, estimated to occur in $1 / 5700$ to $1 / 20,000$ pregnancies. ${ }^{2}$ Here we are presenting a unusual case of 38 years female with posterior rupture of unscarred uterus during labour. The purpose of presenting the case is to focus light on possibility of rupture in unscarred uterus so that medical personel, obstetricians and health worker should be prepared for this dreaded complication while conducting or assisting the delivery in multiparous women with no previous history of uterine scar.

\section{CASE REPORT}

A 38 years old gravid 6, parity 4, abortion 1 and 3 live issues came to our hospital with complaints of 9 months of amenorrhea with pain abdomen with loss of fetal movement since, 3 hours. All her previous deliveries were full term vaginal deliveries with good size babies. Her first issue was male and died just after birth. Rest three issues were female. 1 year back she aborted spontaneously and dilatation and curettage was done in a 
local health centre. During the current pregnancy, she developed labour pain in the morning and was taken to Women's District Hospital at 1 pm where she was given some medications in order to augment the labour. Suddenly she felt strong uterine contraction and absence of fetal movement. Then dramatically her contractions subsided. She was immediately referred to higher centre. Then she came to our hospital.

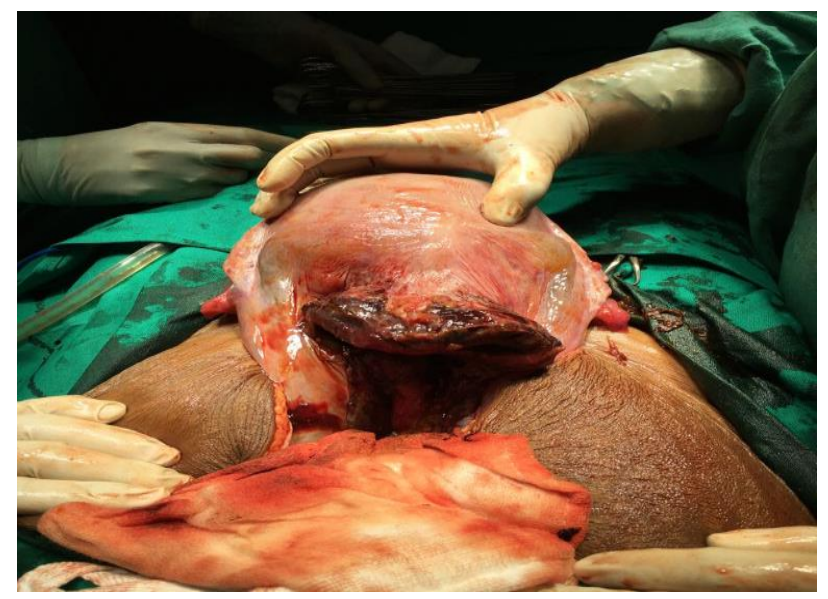

Figure 1: Posterior rupture.

The patient's general condition was poor. Immediately the patient was admitted, vitals taken and i. v. drip of ringer lactate started. On clinical examination patient appeared pale. Her pulse was 112 per minutes and blood pressure records $116 / 76 \mathrm{~mm} \mathrm{Hg}$. She was afebrile, and her respiratory rates were within normal limits. On abdominal examination, the smooth contour of uterus was lost. Uterine bulge was approximately 36 weeks size. Fetal parts were felt distinctly per abdomen above the umbilicus. No uterine contractions present. Fetal heart sound couldn't be localized with stethoscope. Mild bleeding present on per speculum examination. On per vaginal examination cervix was open, multiparous and loose hanging, soft and head was felt high up in the vaginal cavity. Two units blood was arranged and patient was taken for exploratory laprotomy. Intra-operatively as the abdomen was opened, hemo peritoneum of about 11.5 litres was present along with overdistented bowels. Anterior surface of uterus was intact with fetal parts protruding into abdominal cavity. Whole of uterus was explored. A rent was present on the posterior surface extending upto the lower segment. A $4 \mathrm{~kg}$ male IUD fetus was extracted by breech along with placenta. On further exploration, there was a $15-16 \mathrm{~cm}$ tear on posterior wall of uterus extending up to the internal os of cervix. The tear appeared to be fresh but irrepairable. So, decision for hysterectomy was taken. Hysterectomy was done with consent and homeostasis achieved.

\section{DISCUSSION}

Disruption in the continuity of the all uterine layers (endometrium, myometrium and serosa) any time beyond
28 weeks of pregnancy is called rupture of the uterus. ${ }^{3}$ In developed country the frequency of primary rupture approximates 1 in 10,000 to 15,000 births. $^{4,5}$ One reason is a decreased incidence of women of great parity. 6,4 Another is that excessive or inappropriate uterine stimulation with oxytocin previously a frequent cause has mostly disappeared. Anecdotally, however, primary uterine rupture has been encountered in a number of women in whom labor was induced with prostaglandin E1. But in developing country the overall prevalence widely varies from 1 in 2,000 to 1 in 200 deliveries. $^{6}$

A handful of cases have been reported on uterine rupture including both scarred and unscarred uterus like that of McLellan, Nagy, Saglamtas et al, Levrant and Wingate, Hawe and Olah, Kindig et al, Sciscione et al, Wing et al., Langton $\mathrm{J}$ et al. ${ }^{7-15}$

Among these, cases have been reported on posterior rupture of uterus in scarred uterus like that of Wang $\mathrm{P}$ et al and Navaratnam K et al 2011. ${ }^{16,17}$ As far as rupture of unscarred uterus is concern, a few cases have been reported. Case reported by Langton $\mathrm{J}$ et al in had a vertical $2 \mathrm{~cm}$ tear located above the insertion of the right uterosacral ligaments. ${ }^{15}$ Whereas case reported by Yi-Hui Lin et al in 2003 had a laceration about $1 \mathrm{~cm}$ in length over the left cornu. ${ }^{19}$ Our case of posterior rupture of unscarred uterus is a very rare event and there has been hardly any case reported so far.

There has been number of causes enumerated in different literatures regarding uterine rupture. According to Williams some of the causes are given in Table 1.

In present case multi-parity and previous history of and curettage became a predisposing factor for spontaneous rupture. Again, a good size baby in the current pregnancy along with history of labour augmentation in women's district hospital adds more favourable factors for uterine rupture. Cases have been reported regarding rupture in oxytocin augmentation. One study by Kanika Batra and et al in 2010-2012 shows there is $16.6 \%$ risk of rupture of uterus with labour induction. ${ }^{19}$ Thus while augmenting labour in a patient we should always keep this catashtroph as complication in our mind even if the patient has no history of previous cesarean secton or mayomectomy.

Apart from the cause, the site and extent of rupture also to be noted. Rupture of the previously intact uterus during labor most often involves the thinned-out lower uterine segment. When the rent is in the immediate vicinity of the cervix, it frequently extends transversely or obliquely.

When the rent is in the portion of the uterus adjacent to the broad ligament, the tear is usually longitudinal. Although these tears develop primarily in the lower uterine segment, it is not unusual for them to extend upward into the active segment or downward through the cervix and into the vagina. In my case the rupture was in 
middle of the posterior uterine wall, longitudinal and in lower segment extending in both upper segment and below upto internal os of the cervix. This was unusual according to above literature.

Table 1: Some causes of uterine rupture.

Pre-existing Uterine injury or Anomaly
1. Surgery involving the myometrium
- Caesarean delivery or hysterotomy
- Previously repaired uterine rupture
- Myomectomy incision through or to the endometrium
- Deep cornual resection of interstitial fallopian tube
metroplasty

2. Coincidental uterine trauma

- Abortion with instrumentation - sharp or suction curette, sounds

- Sharp or blunt trauma- assaults, vehicular accidents, bullets, knives

- Silent rupture in previous pregnancy

\section{Congenital}

- Pregnancy in undeveloped uterine horn

- Defective connective tissue-Marfan or Ehlers- Danlos syndrome
Uterine Injury or Abnormality Incurred in Current Pregnancy

\section{Before delivery}

- Persistent, intense, spontaneous contraptions

- Labor stimulation- oxytocin or prostaglandins

- Intraamnionic instillation- saline or prostaglandins

- Perforation by internal uterine pressure catheter

- External version

- Uterine overdistention- hydramnios, multifetal pregnancy

During delivery

- Internal version second twin

- Difficult forceps delivery

- Rapid tumultuous labor and delivery

- Breech extraction

- Fetal anomaly distending lower segment

- Vigorous uterine pressure during delivery

- Difficult manual removal of placenta

Acquired

- Placental accrete syndromes

- Gestational trophoblastic neoplasia

- Adenomyosis

- Sacculation of entrapped retroverted uterus
The most common sign of uterine rupture is a nonreassuring fetal heart rate pattern with variable heart rate decelerations that may evolve into late decelerations and bradycardia.

Some experience sudden cessation of uterine contraction. The various Phase of rupture are:

- There is a sense of something giving way at the height of uterine contraction.

- The constant pain is changed to dull aching pain with cessation of uterine contractions.

- General examination reveals features of exhaustion and shock.

- Abdominal examination reveals
i. superficial fetal parts,
ii. absence of FHS,
iii. absence of uterine contour and
iv. two separate swellings, one contracted uterus and the other-fetal ovoid.

- Vaginal examination reveals-

i. recession of the presenting part and

ii. varying degrees of bleeding. In our patients the findings on examinations were same except our patient was hemodynamically stable which was unusual.

\section{CONCLUSION}

Uterine rupture though a dreaded complication of scarred uterus should not be forgotten in women with previous normal vaginal deliveries. Obstetricians and health worker should be vigilant for the signs of this catastrophe. As in our country the multiparous women are delivered at home by the trained nurses and dais, so they should be taught to detect an impending uterine rupture a refer the patients timely. Keeping such complications in mind, institutional deliveries should be encouraged especially in scarred uterus and grand multiparous patient.

\section{Funding: No funding sources \\ Conflict of interest: None declared \\ Ethical approval: Not required}

\section{REFERENCES}

1. Cunningham FG, Leveno KJ, Bloom SL. Williams Obstetrics, 24th Ed. McGraw-Hill Education, New York, Chicago, San Francisco, New Delhi;2014. ISBN: 978-0-07-179894-5.

2. Dow M, Wax JR, Pinette MG, Blackstone J, Cartin. Third-trimester uterine rupture without previous 
cesarean: a case series and review of the literature. Am J Perinatol. 2009;26:739.

3. DC Dutta, Text Book of Obstetrics. $7^{\text {th }}$ Ed. New Delhi, London, Philadelphia;2013. ISBN 978-935152-067-2.

4. Miller DA, Goodwin TM, Gherman RB, Paul RH. Intrapartum rupture of the unscarred uterus. Obstet Gynecol. 1997;89:671-3.

5. Porreco RP, Clark SL, Belfort MA, Dildy GA, Meyers JA. The changing specter of uterine rupture. Am J Obstet Gynecol. 2009;200(3):269-e1.

6. Maymon R, Shulman A, Pomeranz M, Holtzinger M, Haimovich L, Bahary C. Uterine rupture at term pregnancy with the use of intracervical prostaglandin E2 gel for induction of labor. Am J Obstet Gynecol. 1991;165(2):368-70.

7. McLellan AN. Rupture of a pregnant diverticulum of the uterus. Glasgow Med J. 1916;3;390-5.

8. Nagy PS. Placenta percreta induced uterine rupture and resulted in intraabdominal abortion. Am J Obstet Gynecol. 1989;161:1185-6.

9. Sağlamtas $M$, Vicdan $K$, Yalcin $H$, Yilmaz Z, Yeşilyurt H, Gökmen O. Rupture of the uterus. Int J Gynecol Obstet. 1995;49(1):9-15.

10. Levrant SG, Wingate $M$. Midtrimester uterine rupture. A case report. J Reprod Med. 1996;41:186190.

11. Hawe JA, Olah KS. Posterior uterine rupture in a patient with a lower segment caesarean section scar complicating prostaglandin induction of labour. $\mathrm{Br} \mathbf{J}$ Obstet Gynecol. 1997;104,:857-8.

12. Kindig M, Cardwell M, Lee T. Delayed postpartum uterine dehiscence. A case report. J Reprod Med. 1998;43:591-2.

13. Sciscione AC, Nguyen L, Manley JS et al. Uterine rupture during preinduction cervical ripening with misoprostol in a patient with previous caesarean delivery. Aus N Z J Obstet Gynecol. 1998;38:96-97.

14. Wing DA, Lovett K, Paul RH. Disruption of prior uterine incision following misoprostol for labour induction in women with previous Caesarean delivery. Obstet Gynecol. 1998;91:828-30.

15. Langton J, Fishwick K, Kumar B, Nwosu EC. Spontaneous rupture of an unscarred gravid uterus at 32 weeks gestation. Hum Reprod. 1997;12:2066-7.

16. Wang PH, Yuan CC, Chao HT, Yang MJ, Ng HT. Posterior uterine wall rupture during labour: Case report. Hum Reprod. 2000;15(5):1198-9.

17. Navaratnam K, Ulaganathan P, Akhtar MA, Sharma $\mathrm{SD}$, Davies MG. Posterior uterine rupture causing fetal expulsion into the abdominal cavity: a rare case of neonatal survival. Case Reports Obstet Gynecol. 2011;2011.

18. Lin YH, Chen CP, Lin JR, Yeh LF, Chen TC. Thirdtrimester spontaneous rupture of an unscarred uterus with massive intra-abdominal hemorrhage during tocolysis in a pregnant woman who has had multiple instrumental abortions. Taiwanese J Obstet Gynecol. 2004;43(3):172-4.

19. Batra K, Gaikwad HS, Gutgutia I, Prateek S, Bajaj B. Determinants of rupture of the unscarred uterus and the related feto-maternal outcome: current scenario in a low-income country. Tropic Doc. 2016;46(2):69-73.

Cite this article as: Nanda K, Singh S, Dhama V, Choudhary R, Azad R. A rare case of spontaneous posterior wall rupture in an unscarred uterus during labour. Int J Reprod Contracept Obstet Gynecol 2017;6:4127-30. 